$$
\begin{gathered}
\text { 어분 종류 및 소맥분 함량이 다른 배합사료가 } \\
\text { 넙치 (Paralichthys olivaceus)의 성장과 소화율에 } \\
\text { 미치는 영향 }
\end{gathered}
$$

김경덕*·김동규·정재훈·김강웅·손맹현·이상민 ${ }^{1}$

국립수산과학원 사료연구센터, ${ }^{1}$ 강릉원주대학교 해양생명공학부

\title{
Effects of the Different Fish Meal and Wheat Flour Content in Extruded Pellet on the Growth and Apparent Digestibility for Olive Flounder Paralichthys olivaceus
}

\author{
Kyoung-Duck Kim*, Dong Gyu Kim, Jae-Hoon Jung, \\ Kang-Woong Kim, Maeng Hyun Son and Sang-Min Lee ${ }^{1}$ \\ Aquafeed Research Center, National Fisheries Research \& \\ Development Institute, Pohang 791-923, Korea \\ ${ }^{1}$ Faculty of Marine Bioscience and Technology, Gangneung-Wonju \\ National University, Gangneung 201-702, Korea
}

\begin{abstract}
A feeding trial was carried out to investigate the effect of different fish meal and wheat flour contents in extruded pellets on the growth and apparent nutrient digestibility of olive flounder Paralichthys olivaceus. Four extruded pellets (HB1, HB1T, HB2 and HB2T) were prepared using two kinds of high quality brown fish meal and low quality tuna fish meal. Two diets (HB1 and HB2) contained two different kinds of brown fish meal, respectively; in HB1T and HB2T, we substituted $50 \%$ of the brown fish meal with $10 \%$ wheat flour. Three replicate groups of fish (initial body weight of $82 \mathrm{~g}$ ) were fed the experimental pellets to visual satiation for 15 weeks. The highest weight gain was observed in fish fed HB1, and weight gain of fish fed HB2 was significantly higher than that of fish fed HB2T $(P<0.05)$. Feeding efficiency for fish fed HB1 was significantly higher than that of fish fed HB1T and HB2T $(P<0.05)$, but was not significantly different from fish fed HB2. Apparent dry matter digestibility in HB1 and HB2 was significantly higher than in HB1T and HB2T $(P<0.05)$. The highest crude protein digestibility was observed in HB1, and protein digestibility in HB1T and HB2 was higher than in HB2T $(P<0.05)$. The results of this study suggest that fish meal quality considerably affects growth and nutrient digestibility of olive flounder fed extruded pellets, and the use of HB1 is recommended over HB1T, HB2 and HB2T for efficient olive flounder production.
\end{abstract}

Key words: Fish meal, Wheat flour, Growth, Apparent digestibility, Olive flounder

서 론

해산어류는 일반적으로 육상동물이나 담수어에 비해 육식 성이 강하고 단백질 요구량이 높아 사료원료 중에서 단백질원 이 차지하는 비율이 높다 (NRC, 1993). 사료내 단백질은 어류 의 성장과 사료 가격에 큰 영향을 미치는 중요한 요인으로 (Lovell, 1989), 사료에 양질의 단백질 함량을 증가시킬 경우 어류의 성장과 사료효율이 향상되는 것으로 알려져 있다 (NRC, 1993). 소맥분은 양식용 배합사료의 탄수화물원으로써 가장 널리 사용되고 있는 원료로써 사료 제조시 성형을 도와주 는 점결제로도 작용하여 미세한 먼지 등의 부스러기를 없애주 고 수중에서 사료의 풀림을 방지하여 사료의 수중 유실을 감소 시키는 역할을 한다. 또한 탄수화물원은 에너지원으로 이용되 기 때문에 사료 단백질을 절약할 수 있으며, 단백질원 및 지질

\footnotetext{
*Corresponding author: kdkim@nfrdi.go.kr
}

원에 비하여 가격이 낮아 양식 대상종에 대한 이용성이 연구되 면 사료단가를 절감 할 수 있는 영양소이다 (Wilson, 1994). 양식사료의 단백질원으로 가장 널리 사용되고 있는 어분은 단백질 함량이 높고, 아미노산 조성의 균형이 좋을 뿐 아니라 어류의 사료섭취에 대한 기호성을 향상시키는 장점을 가지고 있으며, 여러 어종에서 성장률을 향상시킨 어분 단백질의 우 수성에 관한 연구들이 보고되었다 (Andrews and Page, 1974; Tacon and Jackson, 1985). 그러나 어분은 어획량의 변동에 따라 가격이 불안정하고 생산량이 제한적이어서 최근 가격이 급등하고 있는 실정이다. 어분의 품질은 원료의 신선도 및 제조 조건 등에 따라서 차이가 있으며, 어류의 성장과 사료효 율에 영향을 미치는 것으로 보고되었다 (Aksnes and Mundheim, 1997; Jang et al., 2005). 양식 배합사료 제조시 어분은 대상어종의 단백질 요구량 및 어분의 품질을 고려하여 적정량이 사용되어야 할 것이다. 따라서 넙치 양식현장에서 
실용적으로 사용 가능한 고품질 배합사료 개발 및 양식 경쟁 력 향상을 위해서는 어분 가격 및 품질을 고려하여 사료의 품질을 개선시키고 사료원가 절감 및 어류의 성장을 향상시킬 수 있도록 어분 종류별 이용성과 경제성을 규명하는 연구가 필요하다 (Lee et al., 1996).

각기 다른 어분을 사용하여 제조한 실험용 사료로 치어기 넙치를 사육한 기존의 연구에서 넙치 치어의 성장 및 사료효 율은 어분 종류에 따라서 유의한 차이를 보였다 (Jang et al., 2005). 그러나 Jang et al. (2005)의 연구에 사용된 사료는 실험 용 건조사료 형태였으며, 사육기간이 치어기 (11-52 g)에 국한 되어 있어서 실용 배합사료에 적용하기에는 다소 제한적인 면이 있다. 그래서 본 연구에서는 넙치의 성장을 최대화 시킬 수 있는 고품질 배합사료 개발을 위하여 어분 종류 및 소맥분 함량이 다른 배합사료가 육성기 넙치의 성장 및 소화율에 미치는 영향을 조사하였다.

Table 1. Ingredients and nutrient contents of the experimental diets

\begin{tabular}{|c|c|c|c|c|}
\hline & \multicolumn{4}{|c|}{ Diets } \\
\hline & HB1 & HB1T & HB2 & HB2T \\
\hline \multicolumn{5}{|l|}{ Ingredients (\%) } \\
\hline $\begin{array}{l}\text { Brown fish meal } \\
(75.1 \% \mathrm{CP}, 8.9 \% \mathrm{CL})^{1}\end{array}$ & 60 & 33 & & \\
\hline $\begin{array}{l}\text { Brown fish meal } \\
(72.3 \% \mathrm{CP}, 13.0 \% \mathrm{CL})^{2}\end{array}$ & & & 62 & 34 \\
\hline $\begin{array}{l}\text { Tuna fish meal } \\
(54.6 \% \mathrm{CP}, 11.3 \% \mathrm{CL})^{3}\end{array}$ & & 35 & & 35 \\
\hline Krill meal & 2.5 & 2.5 & 2.5 & 2.5 \\
\hline Wheat gluten & 3 & 3 & 3 & 3 \\
\hline Soybean meal & & 3 & & 3 \\
\hline Wheat flour & 26.0 & 16.0 & 27.0 & 17.0 \\
\hline Fish oil & 5 & 4 & 2 & 2 \\
\hline Others $^{4}$ & 3.5 & 3.5 & 3.5 & 3.5 \\
\hline \multicolumn{5}{|c|}{ Proximate composition (dry matter basis) } \\
\hline Crude protein (\%) & 51.8 & 50.2 & 52.1 & 50.4 \\
\hline Crude lipid (\%) & 10.2 & 11.2 & 11.7 & 12.6 \\
\hline Ash (\%) & 11.9 & 14.1 & 10.7 & 12.7 \\
\hline Crude fiber (\%) & 2.0 & 2.2 & 1.9 & 2.6 \\
\hline Gross energy (kcal/g) & 5.3 & 5.2 & 5.3 & 5.2 \\
\hline \multicolumn{5}{|c|}{ Essential amino acid composition ( $\%$ in diet) } \\
\hline Arg & 3.1 & 3.0 & 2.8 & 2.9 \\
\hline His & 2.1 & 1.8 & 1.3 & 1.3 \\
\hline lle & 2.4 & 2.3 & 2.2 & 2.3 \\
\hline Leu & 4.1 & 3.8 & 3.6 & 3.7 \\
\hline Lys & 4.0 & 3.6 & 3.6 & 3.4 \\
\hline Met+Cys & 1.4 & 1.2 & 1.3 & 1.5 \\
\hline Phe+Tyr & 3.7 & 3.6 & 3.6 & 3.6 \\
\hline Thr & 2.2 & 2.1 & 1.9 & 2.0 \\
\hline Val & 2.7 & 2.5 & 2.5 & 2.6 \\
\hline
\end{tabular}

${ }^{1}$ Produced from Chile.

${ }^{2}$ Produced from Denmark.

${ }^{3}$ Produced in Korea.

${ }^{4}$ Contained vitamins, minerals and additives.
재료 및 방법

실험사료 및 실험어 사육관리

실험사료는 넙치의 영양소 요구 (Lee et al., 2000; Lee et al., 2003; Kim and Lee, 2004)를 고려하여 4종류의 부상 배합사 료 (HB1, HB1T, HB2, HB2T)를 설계하였으며, 원료조성 및 영양성분 분석 결과를 Table 1에 나타내었다. 실험사료의 원료 는 시판사료에 주로 사용되고 있는 원료들로 선정하였다. 단 백질원으로 어분, 크릴밀, 대두박 및 밀글루텐을 사용하였으 며, 지질원과 탄수화물원으로는 어유와 소맥분을 각각 사용하 였다. HB1과 HB2에는 주요 단백질원으로 시중에 유통 중인 상급의 갈색어분 두 종류를 각각 사용하였으며, $\mathrm{HB} 1 \mathrm{~T}$ 와 $\mathrm{HB} 2 \mathrm{~T}$ 는 $\mathrm{HB} 1$ 과 $\mathrm{HB} 2$ 에 사용된 갈색어분 대신 단백질 함량이 비교적 낮은 참치어분을 각각 $35 \%$ (어분 단백질의 $50 \%$ 대체) 첨가하고 소맥분을 $10 \%$ 감소시켜 사료단가가 낮아지도록 설 계하였다. 이렇게 설계된 실험사료는 사료회사에 의뢰하여 부상 배합사료의 형태로 제조하였다.

사육실험은 외형적으로 건강한 평균체중 $82 \pm 1.1 \mathrm{~g}$ 의 실험 어를 선별하여 12 개의 2 톤 원형수조에 각각 50 마리씩 실험구 별로 3반복으로 수용한 후, 실험사료를 1일 2회 (9:00, 17:00) 각 수조에 만복으로 공급하며 15 주간 실시하였다. 사육수는 각 수조에 분당 $20 \mathrm{~L}$ 로 조절하여 흘려주었고 사육기간 동안의 평균수온은 $22 \pm 2.5^{\circ} \mathrm{C}$ 였다.

어체측정 및 성분분석

어체 측정은 사육실험 시작시와 종료시에 측정 전 48시간 절식시킨 후, 각 수조에 수용된 실험어 전체의 무게를 측정하 였다. 어체 성분분석을 위하여 사육실험 종료시 각 실험수조 에서 5 마리의 실험어를 시료로 취하여 냉동 $\left(-25^{\circ} \mathrm{C}\right)$ 보관하였 다. 실험사료와 실험어의 수분은 $135^{\circ} \mathrm{C}$ 에서 2 시간 건조 후 측정하였으며, 조단백질 $(\mathrm{N} \times 6.25)$ 은 Auto Kjeldahl System (Gerhardt VAP50OT/TT125, KG, Germany)을 사용하여 분석 하였다. 조지방은 조지방추출기 (Velp SER 148, Usmate, Italy) 를 사용하여 ether로 추출한 후 측정하였으며, 조회분은 $550^{\circ} \mathrm{C}$ 에서 6시간 동안 회화 후 측정하였다. 사료의 에너지량은 열량 분석기 (Parr-6200, Moline, IL, USA)를 사용하여 분석하였으 며, 아미노산 함량은 아미노산 자동분석기 (Biochrom 30, England)를 사용하여 분석하였다. 실험사료와 분의 산화크롬 함량은 시료의 크롬 함량을 원자흡광분광광도계 (ZEEnit 700, Analyticjena, Germany)를 사용하여 분석한 후, 분자량 값으로 환산하여 측정하였다.

\section{소화율 측정}

실험사료의 소화율 측정을 위하여 사육실험에 사용된 사료 를 분쇄하여 사료 $100 \mathrm{~g}$ 당 산화크롬 $0.5 \mathrm{~g}$ 을 첨가하고 혼합한 후, 실험용 사료제조기로 소화율 측정용 실험사료를 압출 성 형하였다. 자체적으로 설계 제조한 분 수집 장치가 연결된 $500 \mathrm{~L}$ 실험수조 (Fig. 1)에 평균체중 $120 \pm 14.4 \mathrm{~g}$ 의 넙치 육성어 를 실험구별로 각각 20마리씩 3반복으로 수용하였다. 소화율 측정용 실험사료를 오후 2 시에 만복에 가깝도록 공급하고 
오후 5시에 수조 및 분 수집통을 청소한 후, 다음날 오전 10시 에 수집통에 모인 분을 여과하여 시료 채취하였다. 분 수집은 3 주간 실시하였으며, 이 기간 동안의 평균수온은 $24.5 \pm 0.9^{\circ} \mathrm{C}$ 였다. 실험사료의 소화율은 Cho et al. (1982)의 연구에 사용한 아래의 공식으로 계산하였다.

건물 소화율 $=100$ - (사료중의 $\mathrm{Cr}_{2} \mathrm{O}_{3} \times 100$ / 분중의 $\mathrm{Cr}_{2} \mathrm{O}_{3}$ ) 영양소 소화율 $=100$ - [ (분중의 영양소 $\times$ 사료중의 $\mathrm{Cr}_{2} \mathrm{O}_{3}$ )/ (사료중의 영양소 $\times$ 분중의 $\mathrm{Cr}_{2} \mathrm{O}_{3}$ ) $] \times 100$

Table 2. Growth performance of grower olive flounder fed the experimental pellets

\begin{tabular}{lcccc}
\hline & \multicolumn{4}{c}{ Diets } \\
\cline { 2 - 5 } & HB1 & HB1T & HB2 & HB2T \\
\hline Initial mean weight (g/fish) & $83 \pm 0.4$ & $82 \pm 0.4$ & $84 \pm 0.5$ & $83 \pm 0.7$ \\
Mean weight gain (g/fish) & $420 \pm 8.4^{\mathrm{a}}$ & $374 \pm 6.1^{\mathrm{bc}}$ & $396 \pm 5.3^{\mathrm{b}}$ & $360 \pm 8.6^{\mathrm{c}}$ \\
Weight gain (\%) $^{1}$ & $337 \pm 8.6^{\mathrm{a}}$ & $292 \pm 6.1^{\mathrm{bc}}$ & $312 \pm 5.1^{\mathrm{b}}$ & $277 \pm 7.9^{\mathrm{c}}$ \\
Feed efficiency (\%) & $119 \pm 3.7^{\mathrm{a}}$ & $103 \pm 2.0^{\mathrm{b}}$ & $110 \pm 0.6^{\mathrm{ab}}$ & $106 \pm 3.9 \mathrm{~b}$ \\
Protein efficiency ratio $^{3}$ & $2.22 \pm 0.07^{\mathrm{a}}$ & $1.97 \pm 0.04^{\mathrm{b}}$ & $2.11 \pm 0.01^{\mathrm{ab}}$ & $2.11 \pm 0.18^{\mathrm{ab}}$ \\
Daily feed intake (\%) & $1.05 \pm 0.04^{\mathrm{ns}}$ & $1.13 \pm 0.03$ & $1.05 \pm 0.02$ & $1.05 \pm 0.01$ \\
Survival (\%) & $92 \pm 4.2^{\mathrm{ns}}$ & $82 \pm 5.5$ & $81 \pm 3.1$ & $89 \pm 2.9$ \\
\hline
\end{tabular}

Values (mean \pm SE of three replications) in each row with the different superscripts are significantly different $(P<0.05)$.

${ }^{n s}$ Not significant $(P>0.05)$.

${ }^{1}$ (Final body weight - initial body weight $) \times 100 /$ initial body weight.

${ }^{2}$ Fish wet weight gain $\times 100 /$ feed intake (dry matter).

${ }^{3}$ Fish wet weight gain/protein intake.

${ }^{4}$ Feed intake (dry matter) $\times 100 /[$ (initial fish weight + final fish weight + dead fish weight) $\times$ days fed $/ 2]$.

Table 3. Proximate composition (wet weight basis, \%) of the dorsal muscle in grower olive flounder fed the experimental pellets

\begin{tabular}{lcccc}
\hline & \multicolumn{4}{c}{ Diets } \\
\cline { 2 - 5 } & HB1 & HB1T & HB2 & HB2T \\
\hline Moisture & $75.8 \pm 1.03^{\text {ns }}$ & $75.3 \pm 0.35$ & $75.0 \pm 0.18$ & $74.6 \pm 1.07$ \\
Crude protein & $22.8 \pm 0.18^{\text {ns }}$ & $22.9 \pm 0.07$ & $22.2 \pm 0.21$ & $22.2 \pm 0.23$ \\
Crude lipid & $0.27 \pm 0.13^{\text {ns }}$ & $0.25 \pm 0.04$ & $0.18 \pm 0.07$ & $0.25 \pm 0.13$ \\
\hline
\end{tabular}

Values are mean $\pm \mathrm{SE}$ of three replications.

ns Not significant $(P>0.05)$.

Table 4. Apparent digestibility coefficients for dry matter and crude protein of experimental pellets by grower olive flounder

\begin{tabular}{lcccc}
\hline & \multicolumn{4}{c}{ Diets } \\
\cline { 2 - 5 } & HB1 & HB1T & HB2 & HB2T \\
\hline Dry matter (\%) & $81.9 \pm 0.84^{\mathrm{a}}$ & $76.9 \pm 0.41^{\mathrm{b}}$ & $82.3 \pm 0.85^{\mathrm{a}}$ & $73.7 \pm 0.91 \mathrm{c}$ \\
Crude protein (\%) & $94.8 \pm 0.34^{\mathrm{a}}$ & $92.9 \pm 0.37^{\mathrm{b}}$ & $92.3 \pm 0.32^{\mathrm{b}}$ & $89.3 \pm 0.49 \mathrm{c}$ \\
\hline
\end{tabular}

Values (mean \pm SE of three replications) in each row with the different superscripts are significantly different $(P<0.05)$.
통계처리

결과의 통계처리는 SPSS 프로그램을 사용하여 One-way ANOVA test를 실시하고 Duncan's multiple range test (Duncan, 1955)로 평균간의 유의성을 검정하였다.

$$
\text { 결 과 }
$$

어분 종류 및 소맥분 함량을 달리한 부상배합사료로 넙치 육성어를 15 주간 사육한 결과, 생존율은 모든 실험구에서 $81-92 \%$ 였으며, 통계적인 차이는 없었다 (Table 2). 증체량은 상급의 갈색어분만을 사용한 $\mathrm{HB} 1$ 실험구가 $420 \mathrm{~g}$ 으로 가장 높았고, HB2 실험구 $(396 \mathrm{~g})$ 가 두 번째로 높았으며, 참치어분 을 혼합 첨가한 $\mathrm{HB} 1 \mathrm{~T}$ 및 $\mathrm{HB} 2 \mathrm{~T}$ 실험구가 가장 낮은 결과를 보였다 $(P<0.05)$. 사료효율은 $\mathrm{HB} 1$ 실험구가 참치어분을 첨가 한 $\mathrm{HB} 1 \mathrm{~T}$ 및 $\mathrm{HB} 2 \mathrm{~T}$ 실험구에 비해 유의하게 높았지만 $(P<0.05), \mathrm{HB} 2$ 실험구와는 통계적인 차이가 없었다. 단백질효 율은 $\mathrm{HB} 1$ 실험구가 $\mathrm{HB} 1 \mathrm{~T}$ 실험구 보다 유의하게 높았으나 $(P<0.05), \mathrm{HB} 2$ 및 $\mathrm{HB} 2 \mathrm{~T}$ 실험구와 유의한 차이가 없었다. 일일 사료섭취율은 모든 실험구간에서 유의한 차이가 없었다.

사육실험 종료 후, 실험어 등근육의 수분, 조단백질 및 조지 질 함량은 실험구간에 유의한 차이가 없었다 (Table 3). 넙치의 실험사료별 소화율 측정한 결과 (Table 4), 건물 소화율은 $\mathrm{HB} 1$ 과 $\mathrm{HB} 2$ 실험구가 $\mathrm{HB} 1 \mathrm{~T}$ 및 $\mathrm{HB} 2 \mathrm{~T}$ 실험구보다 유의하게 높았 으며, $\mathrm{HB} 2 \mathrm{~T}$ 실험구가 가장 낮았다 $(P<0.05)$. 단백질 소화율은 $\mathrm{HB} 1$ 실험구가 가장 높았으며, $\mathrm{HB} 1 \mathrm{~T}$ 와 $\mathrm{HB} 2$ 실험구는 $\mathrm{HB} 2 \mathrm{~T}$ 실험구에 비해 유의하게 높았다 $(P<0.05)$.

$$
\text { 고 찰 }
$$

본 연구에서 넙치의 성장 및 사료이용률은 사료에 사용된 어분 종류에 따라서 명확한 차이를 나타내었다. 가격이 다소 저렴한 참치어분으로 상급의 갈색어분을 대체한 $\mathrm{HB} 1 \mathrm{~T}$ 및 $\mathrm{HB} 2 \mathrm{~T}$ 실험구는 $\mathrm{HB} 1$ 및 $\mathrm{HB} 2$ 실험구에 비하여 성장 및 사료효 율이 유의하게 저하되는 결과를 보였다. Jang et al. (2005)의 연구에서도 사료에 사용된 어분 종류에 따라 치어기 넙치의 성장 및 사료효율이 유의한 차이를 보여 본 연구 결과와 유사 하였다. Atlantic halibut (Hippoglossus hippoglossus) 및 gilthead seabream (Sparus aurata)과 같은 타 어종에서도 사료 중에 양질의 어분 첨가는 실험어의 성장을 증가시켜 본 연구와 유사한 결과를 보였다 (Anderson et al., 1993; Aksnes and Mundheim, 1997; Vergara et al., 1999). 이와 같이 어류의 성장 및 사료효율은 사료의 단백질 함량이 유사하더라도 단백질원 으로 사용된 어분 종류에 의해 차이를 보였으며, 이러한 차이 는 사료 중에 사용된 어분의 품질 차이에 의한 것으로 판단된 다. 어분의 품질은 어분의 영양소 함량 및 소화율에 따라 달라 질 수 있다 (Romero et al., 1994). 본 연구의 사육실험에 사용된 실험사료의 건물 및 단백질에 대한 넙치의 소화율도 사료 중에 사용된 어분의 종류에 따라서 유의한 차이를 나타내었 고, 실험어의 성장 결과와 건물 및 단백질 소화율이 유사한 변화 경향을 보였다. 사료 중의 영양소 소화율 측정은 사료의 
품질 평가 및 어류의 사료 이용성 평가를 위한 주요한 방법이 다 (Kim et al., 2010). 본 연구에서 실험어가 섭취한 각 사료 중의 영양소의 함량이 유사할지라도 어체 내에서 소화되어 에너지 및 성장을 위해서 사용된 영양소 함량은 차이가 있었 을 것이며, 이러한 소화율 차이가 실험어의 성장 및 사료효율 에 영향을 미친 것으로 판단된다.

Table 5. Production cost (won/kg weight gain) by feeding the experimental pellets

\begin{tabular}{lrrrr}
\hline & \multicolumn{4}{c}{ Diets } \\
\cline { 2 - 5 } & HB1 & HB1T & HB2 & HB2T \\
\hline Feed price (won/kg feed, DM) & 2,796 & 2,459 & 2,861 & 2,485 \\
Feed efficiency (weight gain $\times$ & 119 & 103 & 110 & 106 \\
$\begin{array}{l}\text { 100/feed intake, DM) } \\
\text { Production cost/kg fish }\end{array}$ & 2,350 & 2,387 & 2,601 & 2,344 \\
\hline
\end{tabular}

어분 제조에 사용된 원료의 신선도 및 열처리 조건 역시 어류의 성장 및 사료이용율에 영향을 미치는 것으로 보고되었 는데, 원료의 신선도가 저하될수록 Atlantic halibut의 성장도 는 현저하게 감소하였으며 (Aksnes and Mundheim, 1997), Pike et al. (1990)의 연구에서 어분 원료의 신선도가 낮은 사료 실험구의 연어는 성장, 사료효율 및 사료섭취율이 감소하는 결과를 보였다. 또한 어분 제조 과정 중 열처리 온도의 증가는 gilthead seabream 및 연어의 성장과 단백질 소화율을 저하시키 는 것으로 보고되었다 (McCallum and Higgs, 1989; Aksnes and Mundheim, 1997). Moksness et al. (1995)은 사료 생산 과정에서 고온의 열처리는 원료 중의 유리아미노산 함량에 영향을 미쳐, 을 변형시켜 사료 섭취에 대한 어류의 기호성을 감소시킴으로써 성장을 저하시킬 수 있다고 보고하였다.

어류의 탄수화물 이용성은 어종에 따라 차이가 있으며, 담 수어에 비하여 해산어의 탄수화물 이용성이 낮은 것으로 알려 져 있다 (Wilson, 1994). 어류 사료에 비단백질 에너지원으로 적정 함량의 탄수화물 첨가는 단백질이 에너지원으로 사용되 는 것을 감소시켜 사료의 단백질효율을 증가시키기도 한다 (NRC 1993). 하지만 사료 중에 적정 함량 이상의 탄수화물 첨가는 섭취된 사료의 장통과 시간을 단축시킴으로써 사료의 영양소 소화율을 감소시켜 어류의 성장 및 사료효율을 감소시 키는 것으로 보고되었다 (Falge et al., 1978; Jobling, 1981). 일반적으로 해산어용 배합사료 중에는 $20 \%$ 이하의 탄수화물 첨가가 적합한 것으로 보고되었다 (Wilson, 1994). 상업적으로 많이 사용되고 있는 여러 종류의 사료원료에 대한 넙치 육성 어의 영양소 소화율을 조사한 Kim et al. (2010)의 연구에서 동물성 원료인 어분이 식물성 원료인 대두박이나 소맥분에 비하여 높았다고 보고되었다. 본 연구에서 상급의 어분을 사 용한 $\mathrm{HB} 1$ 및 $\mathrm{HB} 2$ 가 참치어분을 첨가한 $\mathrm{HB} 1 \mathrm{~T}$ 와 $\mathrm{HB} 2 \mathrm{~T}$ 에 비하여 소맥분 함량이 오히려 $10 \%$ 높았지만 사료 소화율 및 성장률이 높아진 결과로 볼 때, 소맥분 함량 증가에 의한 영향 을 완전히 배제할 수는 없지만 넙치 육성어의 성장에는 탄수 화물 함량보다는 단백질원으로 사용된 어분의 품질이 사료
이용성에 더욱 주요한 영향을 미치는 것으로 판단된다. Lee et al. (2003)은 탄수화물원으로 덱스트린 (dextrin)을 5-25\% 첨가한 실험사료로 넙치 치어를 사육한 결과, 덱스트린 함량 이 증가함에 따라서 성장 및 사료효율이 증가하여 본 연구와 유사한 경향을 보였으며, 비단백질 에너지원으로 지질보다 탄수화물을 효율적으로 사용한다고 보고하였다.

배합사료의 시판출하 가격은 원료단가 및 사료회사별 이익 률에 따라 다소 차이는 있겠지만, 실험사료를 제조한 사료공 장에 의뢰하여 계산된 $\mathrm{HB} 1 \mathrm{~T}$ 와 $\mathrm{HB} 2 \mathrm{~T}$ 의 $\mathrm{kg}$ 당 가격은 2460 원 및 2490원으로 $\mathrm{HB} 1$ 과 $\mathrm{HB} 2$ 의 2800원 및 2860원 보다 낮았다 (Table 5). 어체 $1 \mathrm{~kg}$ 생산에 소요되는 사료비용은 $\mathrm{HB} 1, \mathrm{HB} 1 \mathrm{~T}$ 및 $\mathrm{HB} 2 \mathrm{~T}$ 가 유사하지만, 출하 크기까지의 양성 기간은 $\mathrm{HB} 1 \mathrm{~T}$ 및 $\mathrm{HB} 2 \mathrm{~T}$ 가 $\mathrm{HB} 1$ 에 비하여 길어지므로 이에 따른 양식장 운영 에 소요되는 비용이 증가하게 될 것이다. 이와 같이 넙치 육성 용 배합사료에 가격이 저렴한 어분 사용은 사료 단가를 낮출 수는 있겠지만, 그 첨가량이 적정 함량이상으로 증가한다면 오히려 양식 넙치 생산 단가를 증가시킬 수도 있다.

이상의 결과로 볼 때, 사료에 사용된 어분의 품질은 넙치의 성장 및 영양소 소화율에 영향을 미쳤으며, 넙치용 실용배합 사료 제조시 적합한 품질의 어분을 선택하여 사용하는 것은 넙치 양식 생산성 향상을 위하여 중요하게 고려되어야 할 것이다.

$$
\text { 사 사 }
$$

본 연구는 국립수산과학원 (고효율 배합사료 개발 및 실용 화 연구, RP-2011-AQ-020)의 지원에 의해 운영되었습니다.

\section{참고문헌}

Aksnes A and Mundheim H. 1997. The impact of raw material freshness and processing temperature for fish meal on growth, feed efficiency and chemical composition of Atlantic halibut (Hippoglossus hippoglossus). Aquaculture 149, 87-106.

Anderson JS, Lall SP, Anderson DM and McNiven MA. 1993. Evaluation of protein quality in fish meal by chemical and biolocal assays. Aquaculture 115, 305-325.

Andrews JW and Page JW. 1974. Growth factors in the fish meal component of catfish diets. J Nutr 104, 1091-1096.

Cho CY, Slinger SJ and Bayley HS. 1982. Bioenergetics of salmonid species: energy intake, expenditure and productivity. Comp Biochem Physiol 73, 25-41.

Duncan DB. 1955. Multiple-range and multiple F tests. Biometrics 11, 1-42.

Falge R, Schpanof L and Jurss K. 1978. Amylase, esterase and protease activity in the intestine content of rainbow trout Salmo gairdneri Rich. after feeding 
with feed containing different amounts of starch and protein. J Ichthyol 18, 283-287.

Jang HS, Kim KD and Lee SM. 2005. Effect of various commercial fish meals as dietary protein sources on growth and body composition of juvenile flounder, Paralichthys olivaceus. J Aquaculture 18, 267-271.

Jobling M. 1981. Dietary digestibility and the influence of food components on gastric evacuation in plaice Pleuronectes platessa L. J Fish Biol 19, 29-36.

Kim KD and Lee SM. 2004. Requirement of dietary n-3 highly unsaturated fatty acids for juvenile flounder (Paralichthys olivaceus). Aquaculture 229, 315-323.

Kim KD, Kim DH, Kim KW, Son MH, Kang YJ, Baek JM and Lee SM. 2010. Effect od dietary wheat flour content on the growth and body composition of the snail, Semisulcospira gottschei. Kor J Fish Aquat Sci 43, 747-750.

Lee SM, Cho SH and Kim KD. 2000. Effects of dietary protein and energy levels on growth and body composition of juvenile flounder Paralichthys olivaceus. J World Aquacult Soc 31, 306-315.

Lee SM, Jeon IG and Lee JY. 1996. Comparison of various fish meal as dietary protein sources for Korea rockfish, Sebastes schlegeli. J Korean Fish Soc 29, 135-142.

Lee SM, Kim KD and Lall SP. 2003. Utilization of glucose, maltose, dextrin and cellulose by juvenile flounder (Paralichthys olivaceus). Aquaculture 221, 427-438.

Lovell RT. 1989. Nutrition and Feeding of Fish. Van Nostrand-Reinhold, New York, U.S.A., 260.

McCallum IM and Higgs DA. 1989. Aspects of protein utilization in juvenile chinook salmon (Oncorhynchus tshawytscha). Nutritive value of marine protein sources considering the effects of processing conditions. Aquaculture 77, 181-200.

Moksness E, Rosenlund G and Lie O. 1995. Effect of fish meal quality on growth of juvenile wolffish, Anarhichas lupus L. Aquacult Res 26, 109-115.

NRC (National Research Council). 1993. Nutrient requirements fish, National Academy Press, Washington, DC, U.S.A. 114.

Pike IH, Andorsdottir G and Mundheim H. 1990. The role of fish meal in diets for salmonids. IAFMM Technical Bulletin No. 24, 2 College Yard, Lower Dagnall Street, St. Albans, herts. AL3 4PA, U.K., $1-35$.

Romero JJ, Castro E, Diaz AM, Reveco M and Zaldivar J. 1994. Evaluation of methods to certify the 'premium' quality of Chilean fish meals. Aquaculture 124, 351-358.

Tacon AG and Jackson AJ. 1985. Utilisation of conventional and unconventional protein sources in practical fish feeds. In: Cowey CB, Mackie AM and Bell JG. (ed.) Academic Press, London, U.K., 119-145.

Vergara JM, Lopez-Calero G, Robaina L, Caballero MJ, Montero D, Izquierdo MS and Aksnes A. 1999. Growth, feed utilization and body lipid content of gilthead seabream (Sparus aurata) fed increasing lipid levels and fish meals of different quality. Aquaculture 179, 35-44.

Wilson RP. 1994. Utilization of dietary carbohydrate by fish. Aquaculture 124, 67-80.

2011년 3월 15일 접수

2011년 5월 2일 수정

2011년 6월 8일 수리 